\title{
Article \\ Climate Change, Security, and the Resource Nexus: Case Study of Northern Nigeria and Lake Chad
}

\author{
Samuel Stephen Wakdok ${ }^{1}$ and Raimund Bleischwitz ${ }^{1,2, *}$ \\ 1 Bartlett School of Environment, Energy and Resources, University College London, London WC1H 0NN, UK; \\ samuel.wakdok.19@ucl.ac.uk \\ 2 Institute for Integrated Management of Material Fluxes and of Resources, United Nations University UNU \\ FLORES, 01067 Dresden, Germany \\ * Correspondence: r.bleischwitz@ucl.ac.uk
}

check for updates

Citation: Wakdok, S.S.; Bleischwitz, R. Climate Change, Security, and the Resource Nexus: Case Study of Northern Nigeria and Lake Chad. Sustainability 2021, 13, 10734. https:/ / doi.org/10.3390/su131910734

Academic Editors: Adam P. Hejnowicz and Jessica P. R. Thorn

Received: 8 June 2021

Accepted: 17 September 2021

Published: 27 September 2021

Publisher's Note: MDPI stays neutral with regard to jurisdictional claims in published maps and institutional affiliations.

Copyright: (c) 2021 by the authors. Licensee MDPI, Basel, Switzerland. This article is an open access article distributed under the terms and conditions of the Creative Commons Attribution (CC BY) license (https:// creativecommons.org/licenses/by/ $4.0 /)$.

\begin{abstract}
This paper analyses the impacts of climate change and its implications for human security for the regions of Northern Nigeria and Lake Chad. The introduction identifies a gap between evidence on global environmental change and interactions on the ground; it positions the scope for a deeper understanding of the climate-security-resource nexus in Northern Nigeria and Lake Chad and consequences for the implementation of SDGs (Sustainable Development Goals). The section on methods describes the nexus concept and justifies adopting it. As a result of analysing the region, the paper sheds light on the conflict pathways triggered by failures in land grazing policy, which is further evidenced by a short comparison with Northern Kenya. A potentially novel contribution is discussed in terms of scaling up collaboration and green markets for the future of Lake Chad, along with an integrated agricultural nexus policy, both of which are ambitious in the spirit of mission-oriented policies and delivering on the SDGs.
\end{abstract}

Keywords: climate change; human security; resource nexus; Northern Nigeria; Lake Chad

\section{Introduction}

Climate change is a reality and disproportionately impacts vulnerable societies in the Global South. The continuous rise in temperatures is a driver for changing weather patterns, shifting vegetation zones and sea level rise. People's livelihoods in the Global South are highly dependent on the biosphere. The recent Global Environmental Outlook (GEO 6), published in 2019 by the United Nations Environment Programme (UNEP), the latest Intergovernmental Science-Policy Platform on Biodiversity and Ecosystem Services (IPBES) Assessment Report, dated 2019, the ongoing work from the Intergovernmental Panel on Climate Change (e.g., IPCC AR 6 2021) and the World Bank's report series Turn down the Heat (2012-2014) clearly articulate evidence-based concerns over rising insecurity over water and food; they address risks for regions that might become inhabitable and trigger mass migration, with further repercussions on regional and global security. Altogether, these impacts will raise challenges in meeting the UN's Sustainable Development Goals (SDGs) - and, in particular, an alignment of goals related to environmental policy and an inclusive sustainable growth.

Our paper addresses a gap in the literature between evidence on global environmental change and interactions on the ground. Based on the notion of climate change as a stress multiplier [1], our paper starts from assumptions about multiple existing environmental stress factors affecting livelihoods and governance performance today. The paper adopts a nexus approach, which has been defined as a "set of context-specific critical interlinkages between two or more natural resources used in delivery chains towards systems of provision for water energy, food, land, and materials" [2,3]. The nexus approach is an emerging concept at the interface of academia and international organisations that is considered useful to assess risks and explore opportunities enabling the delivery of a range of SDGs. 
Although numerous regional nexus case studies have been written, there is no such study yet for Northern Nigeria and Lake Chad addressing our scope.

The objective of our article is a deeper understanding of the climate-security-resources nexus in Northern Nigeria and Lake Chad and the consequences for the implementation of SDGs. In line with Biggs et al. [4], our paper underlines the relevance of land use in the nexus concept as well as for livelihoods. It is also in line with the IPBES' new work programme seeking to address the interlinkages among biodiversity, water food, and health in the context of climate change. This regional case study seeks to obtain evidence on impacts of climate change and security challenges in an interaction with environmental policy failures and future challenges. Taking into account the long-term character and the multi-level dimensions of related SDG policies, the paper will also develop three policyrelevant socio-environmental scenarios. Again, this is a novel contribution given a gap in the literature in futures thinking based on a geographic context with outlooks on the SDGs [5]. A recent paper by Thorn et al. [6] identifies such a gap after a literature review on participatory planning to envision the futures of mountain social-ecological systems around the themes of governance, economy, land use changes and biodiversity. In a similar research perspective, Miedzinski et al. [7] propose policy roadmaps and mission-oriented policies to help deliver the SDGs. Our article thus seeks to add novelty by (i) providing a multi-disciplinary case study on Northern Nigeria and Lake Chad and by (ii) developing exploratory scenarios about an inclusive and green growth in the region.

Addressing these gaps via our case is relevant because Nigeria is a large emerging economy confronting a range of security issues recently, and Lake Chad, which was one of Africa's largest freshwater bodies, has shrunk by some $90 \%$. Over 10 million people across the region need emergency assistance. The United Nations has termed the Lake Chad crisis as "one of the worst in the world". We argue below that climate change was not initially high on the government agenda in Northern Nigeria, although it had already been disrupting lives and places around the world. Obviously, there were early proactive warnings about climate change becoming a major threat to global security due to the escalating competition for increasingly scarce resources [8] with impacts on human security $[9,10]$, but only few scholars in Nigeria proactively postulated that climate change would pose a challenge to the natural resource base and policies in the country.

Testing our approach, the paper analyses the case with a specific focus on land use and grazing policies in Nigeria; we explore a security and conflict pathway from agricultural practices, land use policy and livelihoods, combined with long-standing competition over resources between farmers and migrating herdsmen. Doing so allows us to test the hypothesis of climate change being a stress multiplier rather than a direct driver of conflicts. Using the analytical nexus framework, the paper also compares our findings with a brief case study in Northwest Kenya written by Daher et al. [1]; conclusions are drawn with care. In line with our aim to use such analysis to help in delivering the SDGs, this article develops a vision and scale-up scenarios for green markets in the region by presenting three scenario narratives that aim to explore potential future transformations of Lake Chad. The article hopes to contribute to envisioning opportunities and risks that can be assessed using our nexus approach towards more inclusive and sustainable growth beyond 2030 .

The next section elaborates on the nexus concept and how it can be used as a method for the scope of this paper. Subsequent Sections 3 and 4 analyse the case and develop scenarios. Afterwards, we summarise results and discuss findings related to our scope and in the wider context of inclusive green policies in Africa and the SDGs. Our conclusions develop messages from our work and recommendations for policy and research.

\section{Methods: The Nexus Concept as a Novel Approach}

The nexus concept has been emerging since the Bonn 2011 Conference, "The Water Energy and Food Security Nexus-Solutions for the Green Economy", with significant involvement from the UN and other international organisations. It has been defined as a "set of context-specific critical interlinkages between two or more natural resources used 
in delivery chains towards systems of provision" [3]. From a policy perspective, it looks at delivery chains of resources, such as water and energy, in a polycentric manner, i.e., as independent providers based on ecosystem services with interlinkages across delivery stages, but without a presumed hierarchy among those dimensions. Thus, water, energy and food are seen as interrelated and of equal priority for the SDGs, considering the specific conditions of their provision and the strategic interests of relevant actors.

Our paper draws on this nexus concept for the following reasons: it helps in understanding the interface between global and local drivers for environmental risks; it looks at the interface of using multiple natural resources and their delivery chains in a regional context; it contributes to a holistic understanding of the SDGs and strengthens those goals that cross-cut inclusive and sustainable growth (SDG 8), life on land (SDG15) and strong institutions (SDG 16).

While the nexus offers a promising conceptual approach, the development and use of specific rigorous methods to systematically evaluate interlinkages or support policy development has been limited. There is no specific nexus method yet, but rather a mix of different methodologies that are applied according to the scope of research, such as InputOutput Analysis based on water or other "footprints" and the use of Sankey diagrams, and a range of qualitative and semi-quantitative tools (e.g., Water Evaluation Planning, WEAP, Long-range Energy Alternatives Planning, LEAP). This paper uses the following methods in relation to the nexus approach: (i) a case study approach based on a scoped literature survey and interdisciplinary insights transcending environmental research and policy analysis, (ii) a cautiously crafted comparative approach with a paper analysing our scope for Kenya [1], where we seek to counter risks of oversimplification across both cases by key references underlining specific circumstances and (iii) a scenario approach addressing gaps in the literature as stated above that follows selected nexus papers on this topic and recent foresight literature [1,2]. While being a research-based concept, it is important to underline that the nexus does inform implementation strategies, for instance via a Water-Energy-Food Knowledge-Action Network hosted by Future Earth and the WEF security resource platform. As a bottom line, it is thought that the nexus concept helps to overcome a silo mentality leading to the SDGs being pursued in isolation, where interlinkages are potentially underassessed or even overlooked.

\section{The Case of Northern Nigeria}

Nigeria, with a population of about two hundred million people and thirteen million cattle, is faced with the impacts of both climate change and unsustainable population growth, as this population is expected to double by 2050. Nigeria has a land mass of about $923,800 \mathrm{~km}^{2}$ and a total surface area of about 91 million hectares [11]. However, Nigeria's large and rapidly growing population is putting dire pressure on the environment and its limited resources, which are also threatened by climate change.

Writers like Okoli et al. [12] argue that desert encroachment triggered the disappearance of grazing and fertile lands, thus indicating a causation between climate change and rising human insecurity in Nigeria. But Benjaminsen et al. [13] opine that political failures such as allowing for ungoverned spaces, rent seeking and intrusion are the main factors underlining a lack of authority and legitimacy as drivers for conflicts and weakening security. Ironically, the latter did not consider the role of climate change as a possible reason for scarcity of resources and the incursion on farmlands by migrating herdsmen. We propose that resource scarcity, worsened by climate change and institutionally determined access to resources, have aggravated conflicts and insecurity in Northern Nigeria.

To illustrate this perspective, we briefly look back on the last twenty years. As the twentieth century came to an end, while some urban areas in Nigeria faced rising crime and social insecurity due to rapid unplanned urbanization [14], rural areas were generally safer in terms of social and physical security, with most of the dwellers earning their living from subsistence agriculture. There was generally a low level of crime, conflicts and physical insecurity among the rural dwellers. For quite a long time, the northern 
part of the country featured the Sahel savanna for farming and pastoralism. The central part, with its lowland rain forest and savanna, served as the food basket of the country, attracting nomadic herdsmen who moved southwards during dry seasons in search of pasture and water, and then northwards during the wet season. The southern part, with its heavy rain and mangrove forests, had plantation farmers, fishermen and some Fulani pastoralists (also called herdsmen); the latter have been moving across the northern and southern parts of the country between seasons. During those previous years, security was not beyond government control, while the citizens could engage in their socio-economic activities freely.

However, the changing climate now makes shifting weather patterns and water insecurity more unpredictable, extreme and stressful; those factors started to exceed the intimate understanding of natural rhythms associated with climate and weather across different temporal scales within the different groups competing for access to land. Rising competition by Fulani nomads for a depleting grazing land caused by climate change and overgrazing pitched the migrating herdsmen against indigenous farming communities [15]. According to Amobi and Onyishi [16], Nigeria, with its location and unique ecology, is now highly susceptible to the fluctuating effects of climate change, which further extends the insecurity as nomadic herdsmen from the north move downwards towards the central and southern states in search of grazing land for their cattle.

In terms of community cohesion and livelihood sustainability, communities have become increasingly insecure in a tightening competition over scarce resources, as the Sudan savanna of the northern and middle parts of the country transits to pure Sahel, and the influence of the Sahara increases southwards. As the ecology of the Guinea savanna gives way to Sudan savanna grassland, the nomadic herdsmen of the lower Sahel and Sudan savanna ecosystems migrate to the Guinea savanna and forest belt of the South [17]. This can be seen as a regime shift in the regional vegetation and land use cover, and part of a larger transition, or potentially an escalation, towards insecurity and conflicts.

Following Slettebak [18], our identification of a regime shift in land use in northern Nigeria is at a risky intersection between human security and conflicts. The migrating herders sometimes displace communities and farmers in search of perpetual grazing lands while their livestock ravage crops and farmlands, resulting in conflicts or rising insecurity. This is a departure from the past, when the herders stayed intermittently and both parties coexisted peacefully, without any threat of existentialism. Lacking enough grazing land to return northwards to during the wet season, the herders' sojourn southward is no longer temporary. States with more green vegetation such as Plateau, Benue, Taraba, Adamawa and Kaduna have seen various forms of confrontations and violent conflicts between migrating herders and communities over access to scarce resource of land and water exacerbated by climate change.

While Sayne [19] believes that no one knows the full security implications of climate change, it seems also fair to say that the government and people hitherto did not consider the full implication of climate change on security in Nigeria. A relevant observation in our case is the increasing ruthlessness of some attacks. Amidst different attacks on farming communities, an estimated 500 villagers were reportedly killed by suspected armed herdsmen in the farming community of Dogo Nahawa in 2010, and about 100 people were also killed in Barkin Ladi in June 2018, again by suspected armed herdsmen, all in Plateau State $[20,21]$. There have also been incidences of cattle rustling and killings of herdsmen in farming communities, thereby perpetuating the security breach.

We agree with Conroy [22] and Sayne [19] that climate change patterns leading to low rainfalls and approaching deserts, particularly in the last three decades, are responsible for the upsurge in the southward migration of the nomads searching for pasture and water. However, "owing largely to its plurality and ethnic divide, environment-induced migration creates volatile contact and competition between groups of highly conflicting natural resource-dependent livelihood systems" [23]. Because the herdsmen are mainly Fulani and predominantly Muslim, while several farming communities in the central part are largely 
Christian, the conflicts sometimes assume a religious dimension [23]; this seems in line with De Juan and Heinze [24], who conclude on ethnic polarisation being relevant, but not a primary driver for conflicts. Ultimately, climate-induced and resource-driven migration substantially endangers security and creates socio-economic disorders. In our case, there is evidence of such movements escalating fierce competitions and skirmishes over access to natural resources between farming communities and the migrating herdsmen. We wouldn't deny that climate migration also leads to beneficial adaptive outcomes through, for example, allowing people to enter seasonally into the cash economy and send back remittances to their rural homesteads, which promotes development. Our case study, however, reveals little evidence for such benefits of migration, but instead points towards a different direction of increasing conflicts. The next section looks at underlying land use policy patterns that could potentially either drive conflicts or facilitate risk mitigation.

\subsection{Land Use Policy Matters: An Appraisal of Grazing Policies in Nigeria}

Land and water are key natural resources worldwide which are also used for the cultivation of crops and grazing of livestock. It is evident that the wide range of lands which preserve the earth's biodiversity also offer a means for sustenance all around the world. Though both resources and their usage are essential to human existence and ought to be utilized sustainably, human activities such as climate change contribute significantly to the availability or scarcity of land and water. Taiye [25] documents that there are in Nigeria, "about 210 persons and 180 grazing animals per kilometre square of land and 15,000 persons and 12,500 grazing animals per kilometre square of water, leading to high demand for food, water and fodder and stress on the environment". These statistics give a visual interpretation of how transhumance grazing, deforestation and irrigation reinforced by climate change are damaging the environment and biodiversity in Nigeria.

Climate change and other environmental factors also threaten the sustainability of land and water in Nigeria, as elsewhere, with serious implications for food, livelihoods, security, peace and sustainable development. This paper aligns with Okoli and Atelhem [12] on the eco-violence theory, whose key assumption is that insecurity and conflicts are being induced by competition over scarce natural resources. Climate variability is also rapidly worsening resource scarcity, hence creating a conflict pathway driven by scarcity, agricultural practices and migration. Next, we will analyse migration in the context of grazing policies in Nigeria.

\subsection{Previous Grazing Policies}

The southward migration of Fulani herdsmen and their encroachment on farmlands in search of freshwater and grassland for cattle, and the depletion of grazing areas because of unsustainable population growth, have exacerbated the conflicts between the herdsmen and farmers in Northern Nigeria. To address the violence over resources, the Nigerian government initiated or conceptualized different grazing policies: the grazing reserve, grazing route, anti-open grazing reserve, rural grazing area (RUGA) and the National Livestock transformation plan policies.

- Grazing Reserves and Routes Policy:

In 1964, Nigeria's first law on Grazing Reserve was introduced to settle the Fulani nomads on lands with pastures for their livestock, but the policy was poorly implemented. Envisaging the impending resource crisis and a low productivity, the then military government in 1988 decreed the National Agricultural Policy of 1988. At least 10\% of the republic's approximately 10 million acres was to be reserved for grazing. A policy failure led to the acquisition of a dismal 3\% of the proposed areas [26]. Again in recent years, there was an effort to create grazing routes and reserves in some selected states of the federation through the National Grazing Route and Reserve Commission Bill of 2011 [11]. It was rejected by the federal legislators who argued that it was unconstitutional for the federal government to set up grazing routes and reserves across states in a federal system [26]. This policy was also opposed in the central and southern states of Nigeria. 


\section{- RUGA Policy:}

The Rural Grazing Area (RUGA) policy was designed to organize and settle pastoralists on lands providing basic amenities, infrastructure and markets. It is a prototype of 40 units of huts for 10 farmsteads on at least 20 hectares of land, mostly in the central and southern states [27]. However, fears from the people of these states led to uproars and fierce resistance. In questioning the policy and calling for its better handling, Nigeria's only Nobel laureate Wole Soyinka added his voice to the unpopularity of the policy [28]. Amid the uproar from some quarters, the government announced the suspension of the RUGA policy, claiming inconsistency with the approved national livestock transformation plan [29].

- National Livestock Transformation Plan (NLTP):

Consistent with the nation's public announcement trends, Nigeria's Vice President announced that the NLTP would modernise livestock production using a mix of nomadic breeding and ranching that would serve a modernised dairy and meat processing industry. Unfortunately, controversy still trailed the NLTP due to its similarity with the unpopular RUGA policy, because many people believed that the NLTP was an alternate method of implementing the RUGA policy.

\section{- Anti-Open Grazing Policy:}

Ekiti and Benue states were the first states to introduce the anti-open grazing law to tackle the menace of open grazing and the accompanying conflicts. Against the odds, the 2016 Ekiti state anti-grazing policy barred the grazing of cattle and other animals on any land in the state which has not been authorized for ranching by the governor [30]. The Benue state government, effective November 2017, also banned open grazing and requested the setting up of ranches [23]. While states with high casualty like Plateau and Adamawa do not have an anti-grazing law, Miyetti Allah Cattle Breeders Association of Nigeria (MACBAN), an ethno-cultural umbrella body of the Fulani herdsmen, decried the law as contravening the nation's constitution on freedom of movement and the right to settle anywhere in Nigeria [31].

We conclude here on the long-standing experience with migration and grazing policy in Nigeria; what has changed is the more permanent migration induced by resource scarcity over land and water, as well as the increasing violence and security ramifications. The recent anti-open grazing policies in some states may postpone conflicts there, if implemented properly; however, they are likely to lead to a regional shift with increased conflicts in other states, and will need proper enforcement. The next section, therefore, looks at a case with similar environmental challenges in a comparable geographical setting but slightly different institutional mechanisms and development challenges.

\subsection{A Brief Comparative Analysis of Nigeria and Kenya}

Following a similar nexus approach, Daher et al. [1] assess the climate-securityresource nexus in line with other work on the nexus interlinkages and ramifications across utilization of resources [3]. Northwestern Kenya comprises seven counties and is considered arid and semi-arid land, where the predominant livelihood is pastoralism. This same region in Kenya is affected by climate change and, consequently, a rising level of climate induced insecurity [1]. Much like in Nigeria, climate change is manifested in the semi-arid northwestern and northeastern states, but the security implications linked to it due to desertification and low rain falls extend mostly to the north central states of Benue, Plateau, Nasarawa, parts of Kaduna and some northeastern states like Adamawa and Taraba. The first quarter of 2018 witnessed attacks in Benue and Plateau states by alleged armed herdsmen as they sought to expand downwards in search of land and water for grazing [32]. We do not claim to search for specific reasons but observe that, unlike in Kenya's case, the climate security nexus in Nigeria is transported beyond the original location where the climate impact occurs. Just to note, one could argue that in northwestern Kenya, climate impacts are also quite pronounced in different regions from where 
the impacts are directly seen; for example, around Lake Turkana where 300,000 people live on the border of the Omo valley in Ethiopia, Uganda and South Sudan and have had food, water and energy security impacted by climate change as it becomes more difficult to access grazing land and water. If [33] was right, that nearly $64 \%$ of the Nigerian landmass is threatened by desertification which is likely to affect almost 65 million people directly or indirectly, we can then postulate that this figure considered the people both in the climate endangered zone and those in other climate-induced insecurity zones.

Although Nigeria operates a Land Use Act promulgated in 1978 which vested power of lands on the subnational governments [26], most lands in the communities are either privately owned or ancestrally inherited. Most rural lands are not communally owned in Nigeria, unlike the lands in northwestern Kenya, which are jointly owned by the community under group ranches [34]. So far, there are fewer negative reactions to the privatization of lands in Nigeria than in Kenya, based on the article by [1]. However, there are also various tenure regimes in northwestern Kenya with varying degrees of tenure security. This is particularly the case with increasing privatization around Lake Turkana, where there is the largest investment in windfarms in Africa. The same is true in other areas in the north, where since the 1930s there has been a lot of land acquisition by British settlers. The problem in Nigeria, however, is the displacement of farmers or communities from their ancestral lands and villages by armed herdsmen, who sometimes invade the communities or encroach on farmlands to graze their cattle. In reaction to the Federal Government's attempt to create grazing reserves around the country [35], there were calls for the private acquisition of land for ranching by interested herders.

There is an increasing community-based conservation in Kenya's northwestern region [1], which in our opinion has dual implications. As the region battles with climate change, conservation appears to become an appropriate response-although it may limit land available for grazing in the short run. This puts land use under additional stress. There is quite extensive degradation and deforestation in northwest Kenya-leading to soil nutrient mining, soil erosion, the loss of livestock weight and thus the quality and quantity of meat and milk, as well as loss of biodiversity [36,37]. Comparing this deterioration with Nigeria, the migrating herders and the farmers are both deforesting the region, which has dual implications with potentially severe impacts over the next years [38]. The accompanying loss of ecosystem services exposes the region to the approaching desertification and intensifies the conflict, as both farmers and pastoralists compete for waning land and water resources. The long run implication is worsening human and environmental security as land and water become scarcer.

While the region in Kenya is undergoing massive development leading to transformation [1], the same cannot be said of the region in Nigeria. Plummeting crude oil revenue, affecting government expenditure and wider insecurity, have led to a lull in development activities in these areas with consequences for livelihoods, further undermining security as manifested in the sharp rise in kidnappings for ransom. Nigeria faces a more perilous security situation than Kenya, as Table 1 shows. Nigeria is currently the third most terrorized country in the world and the first in Sub-Saharan Africa, while Kenya holds the 23rd position globally and the 10th in Sub-Saharan Africa. Terrorism is defined in the Global Terrorism Index (GTI), published by the US Institute for Economics and Peace (IEP), as "the threatened or actual use of illegal force and violence by a non-state actor to attain a political, economic, religious, or social goal through fear, coercion or intimidation" [39].

Table 1. Comparison of Nigeria and Kenya on SSA Global Terrorism Index (GTI) 2002-2019 (GTI 2020 (p. 50), US IEP).

\begin{tabular}{cccccccc}
\hline No. & Country & Overall Rank & Regional Rank & Change 2002-2019 & Change 2018-2019 & Overall Score \\
\hline 1 & Nigeria & 3 & 1 & 4.805 & -0.286 & 8.314 \\
\hline 2 & Kenya & 23 & 10 & 1.011 & -0.100 & 5.644 \\
\hline
\end{tabular}


According to the Global Terrorism Index, Nigeria had the worst terrorist attacks in Africa, with deaths from the alleged armed herdsmen accounting for $26 \%$ of terror-related deaths in 2019 [39], an indication of increasing insecurity and resource conflicts between the herdsmen and farming communities. We refer to [40] for a statement on climate change and terrorism reinforcing each other through a response loop; however, we also point to the need for more in-depth research on causal loops to also address religious and political issues in a conflict pathway analysis. We conclude that the resource nexus security analytical framework used by [1] in Kenya is useful to apply to our case study of Nigeria to assess impacts of climate change and challenges for governance arising through changing patterns of land use and migration; however, we note that the scope and context differ, and both the violence and the vulnerability seem larger in northern Nigeria due to those specific conditions.

\section{The Climate-Security-Resources-Livelihoods Nexus in the Lake Chad Region}

Given the challenges in the region and expected severe impacts of climate change, we are posing the question of whether it is possible to restore Lake Chad to the stable basin that it was several decades ago and, if so, would that be sufficient to rectify some of these challenges and issues that the subsequent section identifies.

\subsection{The Transformation of Lake Chad}

Lake Chad is an exceptional freshwater lake located on the edge of the arid African Sahara. For 1000 years, until around 60 years ago, Lake Chad was the fourth largest lake and one of the largest bodies of freshwater in Africa, providing sustainable livelihoods for more than 35 million people through farming, fisheries and livestock (Figure 1) [41]. Ref. [42] reports that Lake Chad, home to 120 species of fishes, 372 birds, 44 algae and reedbeds was a key contributor to global biodiversity. Situated in the northern central part of Africa, Lake Chad surrounds four countries-Chad, Cameroon, Niger and Nigeria, with the areas around the lake in these countries referred to as the Lake Chad region. However, the Lake Chad Basin spreads over eight countries: Algeria, Cameroon, Central African Republic, Chad, Libya, Niger, Nigeria and Sudan, covering nearly $8 \%$ of Africa. Geographically, the Chari River, which flows through Chad from the Central African Republic, provides Lake Chad with $90 \%$ of its water, and the Logone River, coming from Cameroon, meets the Chari River somewhere in N'Djamena before connecting with Lake Chad. The level of the lake's water is associated with the variation in the flow from the tributaries which depend on rainfall [43].

However, because of climate change and droughts starting from the 1970s, the inhabitants of the Lake Chad region started following the receding shores as the waters retreated, thereby causing a mass migration and convergence around the lake and its numerous islands, inevitably putting pressure on the lake through irrigation and over utilization of the lake's resources. While [42] and Odada et al. in 2005 [44] agree that Lake Chad shrank to $2000 \mathrm{~km}^{2}$ from its 1960 s peak of $25,000 \mathrm{~km}^{2}$ and is on the verge of vanishing, [45] contend that the lake has since expanded to roughly $14,000 \mathrm{~km}^{2}$. However, despite improved rainfall since 2002, Lake Chad has not recovered, evidently because of Cameroon's Maga dam which diverted $70 \%$ of the Logone River from flowing into the lake to rice farms [45]. Whatever opposing views exist, the consensus is that climate change led to the splitting of the endangered lake into two uneven water bodies, the northern and southern pools, spotting a drought-prone, shrunken landscape within the arid and semi-arid Sahel strip [46]. Addressing this data uncertainty is beyond the scope of this paper. 


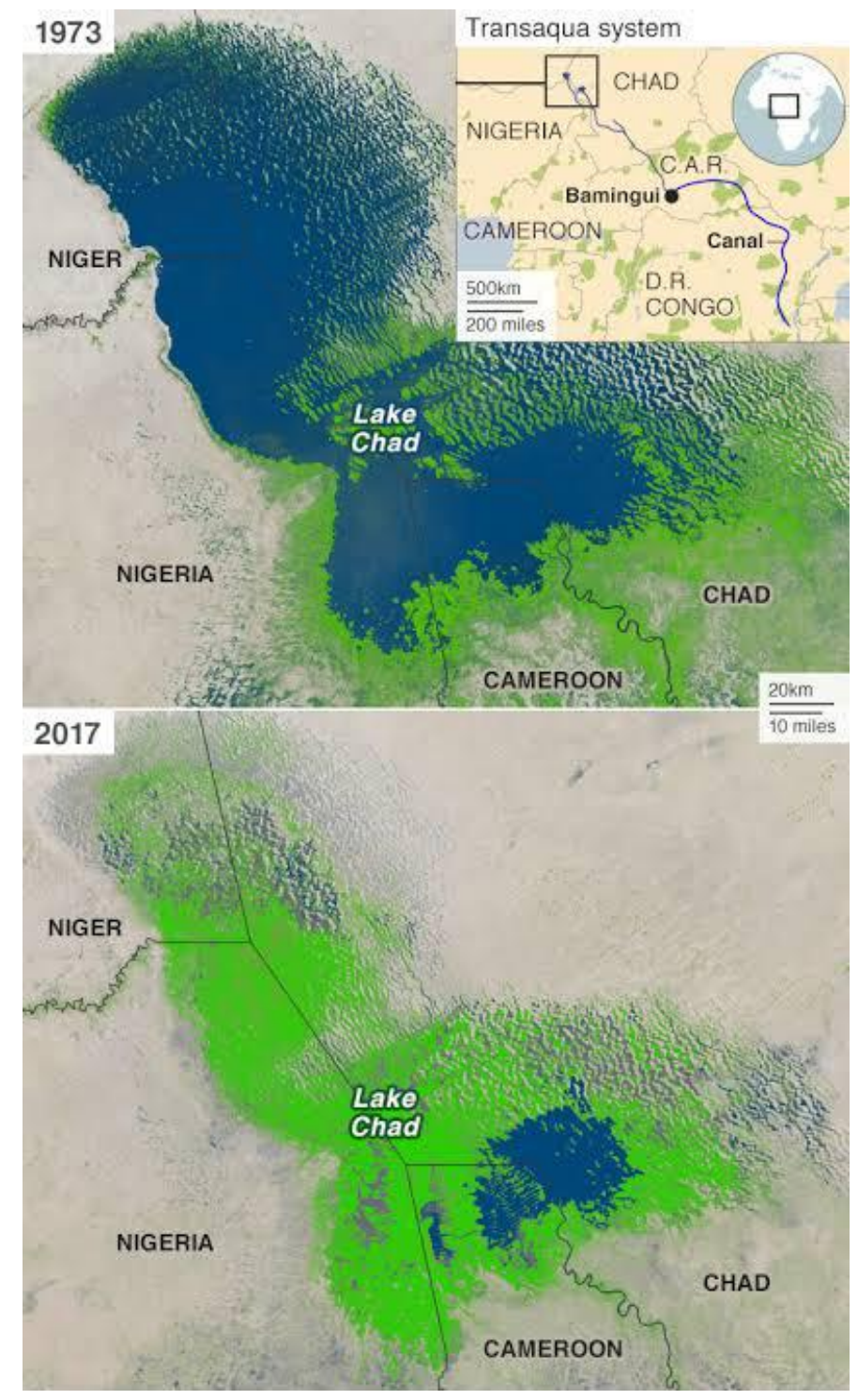

Figure 1. Lake Chad, 1973 and 2017; Source: UN.org.

\subsection{Upcoming Security Challenges in the Region}

We now analyse the transboundary security character of our case. The Boko Haram insurgency makes it difficult for climate change adaptability due to dislodgement of the people, limitations of movement and denied access to resources. This worsened the situation in the Lake Chad region as the insurgency, which started on the Nigerian side in 2009, spilled over to Chad, Niger and Cameroon, triggering a multifaceted humanitarian crisis [47]. While there is limited evidence to show causation between the climate changeinduced shrinking of the lake and the insurgency, there is however a strong correlation, because of the loss of livelihood opportunities and the need for the inhabitants of the Lake Chad region to travel further in search of water and fodder due to, in part, climate change and the diminishing water levels of the lake. Hence, many men and youths of the region were easily recruited into the violent insurgency and terrorism that has killed over 20,000 people, displaced almost three million, exposed more than five million to hunger, put eleven million people in need of humanitarian aid and destroyed infrastructure in the region [48]. A full investigation of those recruitment patterns, however, is beyond the scope of this paper; it may well be that negative impacts on livelihoods and ways of life causes disenchantment and disenfranchisement from the status quo, and more variables would need to be assessed. 
Nigeria retained the position of the third most terrorized country in the world for the fifth consecutive year in 2019, as depicted in Table 2. In 2018, there was a 33\% rise in deaths, while those linked to the extremist herdsmen groups rose by 261\% [39]. However, in 2019 there was a $39 \%$ decrease in total terrorism deaths and a $27 \%$ fall in terror related incidents. The decline was ascribed to a substantial fall in violence linked to Fulani extremists, which are linked to the armed herdsmen [39] (see also Section 3 above).

Table 2. Global Terrorism Index 2014-2019 and the rank of Nigeria. (GTI Reports 2015-2020, US IEP).

\begin{tabular}{ccccc}
\hline S/No & Year & Rank & Score & Change \\
\hline 1 & 2019 & 3 & 8.314 & - \\
\hline 2 & 2018 & 3 & 8.597 & - \\
\hline 3 & 2017 & 3 & 9.009 & - \\
\hline 4 & 2016 & 3 & 9.314 & -1 \\
\hline 5 & 2015 & 3 & 9.123 & 8.58 \\
\hline
\end{tabular}

Terrorism has affected the Nigerian economy negatively (Table 2), costing it 2.4\% GDP in 2019, down from $2.7 \%$ in 2018. In 2018 alone, armed Fulani groups, which are part of the resource conflict, accounted for 1158 killings. This greatly reduced in 2019 to 325 fatalities, indicating a fall of $72 \%$ [39]. While climate variability affects land, the current security situation makes it difficult for those living in volatile areas like the Lake Chad area to explore dry season farming, using the stream for irrigation. In the worst case when the streams dry up, they can no longer access the lake itself, sealing off any means of livelihood.

We emphasise a pathway to insecurity with climate change as an underlying indirect driver while security ramifications are triggered by land use policy practices and by the emergence of organized crime and terrorism with "intrastate and regional interstate conflict pattern" threatening the stability of resource-dependent states such a Nigeria. This is in line with, e.g., [49] and the proposed drivers of a new vulnerability, as well as findings provided by [10] about institutional factors in analysing armed conflicts related to climate change. In accordance with our aims to be policy-relevant and contribute to foresight, we therefore see a need to conceptualise climate justice from the Green Climate Fund, with conditions capturing livelihood and land use policy practices as well as armed conflict patterns; it is not about compensating fossil fuel dependent states but strengthening basic institutions on the ground and building capacity $[5,10]$. We argue below that such funds or new financial mechanisms could be used to potentially recharge Lake Chad, halt desertification and deforestation, and reclaim desert lands to provide enough land for grazing and farming to tackle resource scarcity.

\subsection{Three Scenarios to Explore Possible Futures for Lake Chad}

In line with a stated lack of scenario-based studies in [5] and recent thinking on transformative sustainability research [50], we propose three diverse, plausible desired visions for Lake Chad. The aim of these scenarios is to explore the risks and opportunities of how capital, technology and collaboration could turn the region into an integrated hub as a future destination for sustainable finance and capacity building. Methodologically, it follows a mission-oriented road mapping approach to deliver the SDGs [7]. Singapore's successful "swamp to skyscrapers" transition makes this vision achievable. The reality this vision seeks to create is a safe place where people, planet and possibilities are assured of survival, security and sustainability with one of the scenario models.

Three scenarios are built for this vision. The scenarios are developed by a combination of literature review and expert judgement; a next step could be a participatory co-creation process with stakeholders. While the first scenario is limited in scope, the third scenario is 
more out of the box and ambitious and extends the scale of the second scenario through a more multi-regional approach. The sources of data include: [42,49,51-54].

Scenario 1-Better water engineering driven by Nigeria

This is the lowest cost scenario proposed for Nigeria. The Federal Government of Nigeria channels water from Rivers Niger and Benue, that cause perennial flooding in many states of the country, to the Lake Chad via the Hadejia, Jema'are, Komadugu and Yobe Rivers, which currently contribute about 3\% of the flow into the lake. Other tributaries will actively contribute if properly channelled to feed into the major artery of the lake. The target year to achieve this is 2027 at a hypothetical cost of $\$ 5$ billion, mainly being applied to the transfer of water, although the increased availability of water will not adequately tackle the main cause of shrinking of the lake if the over-exploitation is not first addressed. However, in the absence of other options, this offers a quick stop gap to the shrinking of the lake, especially at its northern pool, which is vanishing and provides some livelihood to people at the mouth of the lake.

Scenario 2-Regional collaboration

This is a possible scenario built upon the ambitious vision of an interbasin water transfer from the Congo Basin's Ubangi River, over 2400 km from the Democratic Republic of Congo. It requires a regional collaboration among the four countries of the Lake Chad region, Cameroun, Chad, Niger and Nigeria, who must pool resources and raise international capital. "The Ubangi River basin straddles the equator from $8^{\circ}$ North to about $12^{\circ}$ South of latitude, its geographic position straddling the equator, and its large size makes this basin relatively unaffected by the seasonal variations in its flow" [42]. With a length over 1000 km, the River Congo's largest tributary is the most renewable and sustainable source of recharging Lake Chad if diverted to the Chari River, which provides 95\% of Lake Chad's water at the southern pool. This scenario halts the shrinking of Lake Chad and boosts its water to a minimum of $90 \%$ of its pre-historical level. Eventually, this will return livelihoods in fishing, farming and livestock across West and Central Africa and enhance sustainability. This intake from the Ubangi River amounts to less than $5 \%$ of the water in the river and only $0.25 \%$ of the water from the Congo River that empties into the Atlantic Ocean. For the sake of our scenario, it is estimated to take about 5 years to refill Lake Chad, so this scenario can be achieved by the year 2030 at an estimated cost of $\$ 23$ billion according to the Lake Chad Basin Commission.

Scenario 3-Scaling up collaboration and green markets

This is the most preferred, though most expensive, scenario. It is built on the bolder, ambitious vision of scaling up scenario 2 beyond recharging the lake to a total quality vision of transfiguring Lake Chad. The pathway for this scenario is, in addition to scenario 2, create an international river with associated transport system that can aid the movement of people, farm produce and other goods to lift trade. Using the Suez Canal model will open the region around the land-locked countries of Chad and Niger, with those of Nigeria and Cameroon thereby creating a conurbation to form an international maritime city. This scenario is built to incorporate the other countries of the Lake Chad Basin Commission, i.e., Libya, Sudan, Algeria and the Central African Republic.

This scenario requires constructing almost $3000 \mathrm{~km}$ of navigable channel, which will serve as a realistic alternative to the Lagos-Mombasa Highway meant to connect East and West Africa, but has suffered many topographical challenges. There will be a flow control dam at Palambo between Congo, Bangui and the Democratic Republic of Congo, and construction of a $160 \mathrm{~km}$ long underpass to link the Chad and Congo basins. It needs river dredging which can discharge close to $1000 \mathrm{~m}^{3}$ of water per second and will reconnect the northern and southern pools of Lake Chad.

An extra $500 \mathrm{~km}$ overflow of water would irrigate the Lake Chad border arid lands and repel encroachment of the Sahara Desert. A sustained tree planting drive of about 100 million trees a year for forestation and afforestation would be needed, along with other measures to enhance carbon sinks in the region and reduce emissions as well as to enhance ecosystem services. Wind and solar farms will be built, capable of generating 
about 10,000 megawatts of power to be distributed pro rata among the countries. The target year for full completion is 2040 and, according to the UNDP, is projected at a cost of $\$ 50$ billion. However, the capital for this scenario can only be sourced by an alliance of International Consortia from the Lake Chad Commission countries, multi-lateral lending agencies and international financial institutions. The stakeholders could use the DesignBuild-Finance-Maintain-Operate model for a return on their investments. The advantage of raising international capital is the additional buy-in from international stakeholders, eventually even with provision of international security from a trans-national military with naval, air force and marine bases, to drive and safeguard this huge investment and help address the security challenges in the region through additional policy learning.

\section{Results}

Our analysis leads to the following results:

\subsection{A Nexus Approach Is Useful for a Deeper Understanding of Climate Change-Land Use-Security}

Our case study confirms the usefulness of the nexus approach, assessing critical interlinkages and looking beyond particular sectors. Especially, the extension of the nexus to land use and related policies helps to understand the drivers of insecurity. The critical threshold is our identification of a regime shift in land use. Nomadic herdsmen of the lower Sahel and Sudan savanna ecosystems migrate from northern Nigeria to the Guinea savanna and forest belt of the South [17]. Together with displacements, this can be seen as a dangerous intersection with human security. Such a regime shift in the regional vegetation and land use cover can become part of a larger escalation towards insecurity and conflicts. Conflicts are aggravated through a religious dimension [23] because the herdsmen are mainly Fulani and predominantly Muslim, while several farming communities in the central part are largely Christian. At the same time, there is an increasing ruthlessness to some attacks and an enhanced involvement with the terrorism of Boko Haram. The recent anti-open grazing policies in some states may postpone conflicts there, if implemented properly; however, they will need proper enforcement and are likely to lead to more regional shifts with increased conflicts in other states. In relation to the broader debate on climate and security, as put forward by Uexkuell and Bulhaug [5], it is therefore the intersection of climate change with land-based ecosystem services, agricultural and migration patterns, and slow and inadequate governance responses, that put people at risk and drive conflicts in the region. Our paper adds nuances on land use policies, long-standing migration patterns and socio-cultural norms that act as triggers for conflicts and potential ramifications in the future.

\subsection{A Comparison Is Difficult, but Can Underline Findings on Land Use Policy and Socio-Cultural Norms}

Using the same resource nexus security analytical framework as used by [1], we see similar impacts of climate change and challenges for governance in Kenya arising through changing patterns of land use and migration. Assessing ecosystem services properly and providing access to land for livelihoods is key in both regions. However, we note that the scope and context differ. Both the violence and the vulnerability seem larger in northern Nigeria due to the displacements as an outcome of land use policy practices and by the emergence of organized crime and terrorism. Our brief comparison thus underlines that it is the displacement issue as a consequence of land use policy and socio-cultural norms and not the ownership models that make the difference. As a consequence, Nigeria and the Lake Chad region appear at larger risk, despite new global players arising in Kenya in the form of oil companies who may trigger corruption and other resource governance challenges. Therefore, we emphasise a pathway to insecurity starting with impacts from climate change but triggered by local and regional drivers of a new vulnerability stemming from access to grazing land, food and water insecurities and displacements, all combined with institutional failures and socio-cultural factors. This is in line with [50] as well as 
findings provided by [10]. Those regional contexts and policies seem to have a stronger impact compared to global drivers and global players.

\subsection{Despite Challenges, Scenarios Can Open Opportunities}

Despite pointing at challenges and potential escalation of conflicts in the future, this paper is combining a nexus approach with mission-oriented policies to identify more sustainable pathways. While issues of water and land use interact quite severely and require expertise in engineering and technology, our results underline the need to address policies and socio-cultural factors, too. Our third and most ambitious scenario transcends water engineering and combines it with access to food and energy and international collaborations. It overcomes the risks of siloed approaches inherent to single sectoral approaches and opens opportunities for a range of SDGs. Proposed in an integrated manner, a strength is the long-term vision for the year 2040 with an International Maritime Zone as a catalyst to a Continental Green Agro-allied Economic Zone. In line with our other results, political buy-in from the Lake Chad Commission countries, other regional stakeholders and international organisations will be key to establishing a platform and mobilising investments for such a policy roadmap to be sustained.

\section{Discussion}

\subsection{A Systemic Policy Option on Grazing: A More Integrated Agricultural Nexus Policy}

Grazing policies are key to resolving the challenges in Nigeria and around Lake Chad. Our identification of such policies as a critical variable on how resource interlinkages are unfolding should lead to thoughts about response options. A straightforward yet difficult policy option available to Nigeria could be an outright ban of open land grazing, which is not popular with the nomadic herdsmen and could lead to increased tensions or conflicts. The more moderate option is the development and implementation of a ranching policy which will flow from the former, but the trade-off is changing the lifestyle of the nomads and the huge monetary cost of providing pastures in the ranches. The third option, on which we elaborate more below, is to review and delineate modern grazing routes in a manner to guide open grazing and prevent encroachment into farms and destruction of the ecosystem while having the ability to provide some sort of open ranching.

This paper suggests using the nexus approach to formulate an Integrated Agricultural Nexus Policy to sustainably tackle the growing scarcity of land and water for crop farming and animal grazing, and the conflicts that arise. This is a follow-on based on recent findings on climate and security $[5,10]$ and will allow for an innovative land use change that integrates forestry, crop farming and livestock grazing. This integrated system will benefit immensely from the interbasin water transfer which comes with the recharging of Lake Chad, especially as detailed in the third scenario developed in this paper. The advantages of this policy include the eco-friendly nature of systems integration, addressing the challenges and needs of multiple stakeholders and the environment. As tested in Brazil, this paper agrees that the four types of system integration can be successfully adopted methodically or comprehensively in Nigeria based on location specifics and availability of funds. "The crop-livestock system which integrates production of grains, grasses and animals; the livestock- forestry system which integrates production of grasses, animals and trees; the crop-forestry systems which integrates production of grains and trees, and finally the crop-livestock-forestry system which integrates production of grains, grasses, animals and trees" [55]. Such policy, if properly developed and adopted, will reclaim land and check desertification. An Integrated Agricultural System will facilitate more sustainable agriculture, which ultimately allows for recycling of nutrients and natural resource efficiency, and also supports incorporating local participation in all the policy making stages as a critical success factor [56]. At a more advanced level, agrovoltaics could also contribute to electricity supply [57]. The proposed green zone could also include sustainable cities, industrial parks, free trade zones and eco-tourism locations. Known for droughts and famine, the region will henceforth have resilient levels of water and food 
security, more energy security, and the people could be granted special citizens' status of "Lake Chad Sustainable Multi-Cities" across the member countries.

The merits of this policy roadmap include responses to climate change, a more optimal and fair utilization of land, forest and water resources, improved food production, increased yield from livestock, agricultural symbiosis, reduced hunger, prevention of conflicts over resources, and potential energy supply, all of which will counter the pathways from resource scarcity to conflicts and will contribute to implementing a range of SDGs. It is also in line with a recently launched programme at the Consortium of International Agricultural Research Centers (CGIAR) on the nexus across Water-Energy-Food-Forest-Biodiversity systems that will be conducted in other regions and may allow for lessons learned; we also note comparability to a study on climate adaptation and governance in an Alpine region conducted by Cattivelli [58]. Our results also feed into IPCC work on co-benefits and ongoing IPBES work on benefits people can obtain from ecosystem services at IPBES.

\subsection{Challenges in Scenario Development and Impact Assessments}

The ambitious vision of transforming Lake Chad comes with some challenges that must be addressed. The first challenge is funding, because countries of the Lake Chad region are low-income countries which do not have the capacity to mobilize such huge domestic resources in terms of funds, technology and expertise. International capital and technical assistance are needed to achieve this vision. While there have been some pledges by international donors, the outbreak of Covid-19 poses a danger, as countries and the global economy face an unprecedented health pandemic and economic downturn. Our case, however, does raise issues of environmental justice, as large parts of Africa suffer disproportionately from the impacts of climate change while having the lowest footprint per capita of $1 \mathrm{t}$ per year and an insignificant share of about $3.8 \%$ to the world-wide greenhouse gas emissions [11].

Our proposal to reassess the Green Climate Fund and add conditions capturing livelihood and land use policy practices as well as armed conflict patterns would seek to overcome the finance challenge. Another challenge is the insecurity earlier described as the ongoing insurgency ravaging the region, which poses a great threat to lives and investment needed during the construction around the four littoral states. Adding capacity on policy learning about security and merits of collaboration will therefore be pivotal.

There is also the challenge of colonial history and language differences. Nigeria is the only Anglophone country of the four Lake Chad region countries. The Francophone countries have more affinity to France, which may lead to interventions, misunderstandings and red tape. In many instances, corruption and policy inconsistency/reversals are challenges that such capacity would need to encounter. It would also need to address mitigating environmental and social risks the project may pose during the construction of dams and dredging of rivers, which can lead to flooding, displacement and disruption of lives and livelihoods if managed based on limited knowledge and in a non-collaborative manner. To address these challenges and succeed, the Lake Chad Basin Commission could be reactivated and properly funded by member countries to carry out its mandate.

Our findings stress the relevance of conducting both environmental and socio-economic impact assessments for the proposed changes; however, our emphasis on financing and institutional factors rather than technical optimisation is in line with recent analysis on transition management and modelling [2,6,51,59]. Doing so for countries such as Nigeria and our case study region will need to integrate land use policy in pathways to sustainability and policy roadmaps. It could feed into recent programmes on climate-compatible growth and funding lifelines of resilient infrastructures carried out by international donors and the World Bank.

\section{Conclusions and Recommendations}

Studying the intersection of climate change, resource scarcity and security is pivotal to understanding multiple existing environmental stress factors and how they affect 
livelihoods and governance. Based on a nexus approach, our paper confirms failures in land grazing policy in northern Nigeria and the Lake Chad region as a main driver for displacements, which in turn lead to regime shifts in agriculture practices, deterioration of ecosystem services and violent conflicts. In comparison, climate change is more of an underlying driver and stress multiplier. Our case study demonstrates pathways of how environmental impacts, land use policy and socio-cultural factors induce migration, rise tensions and accelerate security challenges in the region and beyond. This is a more inclusive nexus compared to water-energy-food, which clearly shows the need to perform policy analysis with a security angle, studying implications for resources and livelihoods in northern Nigeria.

The implication for research and policy, however, does not need to be pessimistic. In contrast, our approach to developing nexus scenarios for the future in the Lake Chad region and thoughts on an Integrated Agricultural System Policy can be considered novel and can also be utilized to deliver a range of SDGs, especially the SDGs related to food, water, land use and inclusive and sustainable growth. Going beyond the timeframe of the SDGs, transforming the vanishing Lake Chad by 2030-2040 would significantly benefit about 50 million residents of the Lake Chad region. It will revive Lake Chad, will provide livelihoods and security, transform the economy of the lake Chad basin, restore biodiversity and could contribute to reversing main climate impacts. Other policy implications of this paper are the implementation of the suggested Integrated Agricultural System Policy in Nigeria, which will rely on the recharging of Lake Chad and the immediate implementation of the African Continental Free Trade Agreement by the four countries of the Lake Chad region, and possibly the eight members of the basin. If properly formulated and implemented, the Integrated Agricultural Nexus policy can lead to future developments that will see Nigeria becoming a large exporter of crops, livestock and dairies given its size, location and people.

We however realise the limitations of our research and advise that further datadriven and stakeholder-oriented research could be conducted and propose collaborations between academics and policy makers, among member countries and with the international community, to assess risks and address the challenges around collective capacity building associated with our SDG vision for Lake Chad and northern Nigeria. The strands of transition management, participatory modelling and mission-oriented policies should be able to inspire more research at the intersection of climate change, security and the resource nexus in the future.

Author Contributions: Conceptualization S.S.W. and R.B.; methodology R.B. and S.S.W.; analysis, investigation and data S.S.W., writing original draft preparation S.S.W., writing review and editing R.B. and S.S.W., supervision R.B. All authors have read and agreed to the published version of the manuscript.

Funding: This research received no external funding.

Institutional Review Board Statement: Not applicable.

Informed Consent Statement: Not applicable.

Data Availability Statement: Data sharing not applicable.

Acknowledgments: We wish to thank Kate Litwinczuk for support with editing and we express our gratitude to the UCL MSc programme on Sustainable Resources for bringing us together. We also wish to thank the guest editor, Adam Hejnowicz, for his patience with our manuscript and his useful advice.

Conflicts of Interest: The authors declare no conflict of interest. 


\section{References}

1. Daher, B.; Lee, S.; Mohtar, R.H.; Asaka, J.O.; Van Deveer, S.D. Security, climate change and the resource nexus. In Routledge Handbook of the Resource Nexus, 1st ed.; Bleischwitz, R., Hoff, H., Spataru, C., Van Der Voet, E., Van Deveer, S., Eds.; Routledge: London, UK, 2017.

2. Bleischwitz, R.; Spataru, C.; VanDeveer, S.D.; Obersteiner, M.; van der Voet, E.; Johnson, C.; Andrews-Speed, P.; Boersma, T.; Hoff, H.; Van Vuuren, D.P. Resource nexus perspectives towards the United Nations sustainable development goals. Nat. Sustain. 2018, 1, 737-743. [CrossRef]

3. Andrews-Speed, P.; Bleischwitz, R.; Boersma, T.; Johnson, C.; Kemp, G.; VanDeveer, S.D. Want, Waste or War? The Global Resource Nexus and the Struggle for Land, Energy, Food, Water and Minerals; Routledge: London, UK, 2014.

4. Biggs, E.M.; Bruce, E.; Boruff, B.; Duncan, J.M.; Horsley, J.; Pauli, N.; Imanari, Y. Sustainable development and the water-energyfood nexus: A perspective on livelihoods. Environ. Sci. Policy 2015, 54, 389-397. [CrossRef]

5. Von Uexkuell, N.; Buhaug, H. Security implications of climate change: A decade of scientific progress. J. Peace Res. 2021, 58, 3-17. [CrossRef]

6. Thorn, J.P.R.; Klein, J.A.; Steger, C.; Hopping, K.A.; Capitani, C.; Tucker, C.M.; Marchant, R. A systematic review of participatory scenario planning to envision mountain social-ecological systems futures. Ecol. Soc. 2020, 25, 6. [CrossRef]

7. Miedzinski, M.; Mazzucato, M.; Ekins, P. A Framework for Mission-Oriented Innovation Policy Roadmapping for the SDGs: The Case of Plastic-Free Oceans. Available online: https://www.ucl.ac.uk/bartlett/public-purpose/wp2019--03 (accessed on 17 May 2021).

8. Stirrup, J. British Defence in a Changing World. RUSI J. 2007, 152, 20-25. [CrossRef]

9. Adger, W.N.; Pulhin, J.M.; Barnett, J.; Dabelko, G.D.; Hovelsrud, G.K.; Levy, M.; Oswald Spring, Ú.; Vogel, C.H. Human security. In Climate Change 2014: Impacts, Adaptation, and Vulnerability. Part A: Global and Sectoral Aspects; Field, C.B., Barros, V.R., Dokken, D.J., Mach, K.J., Mastrandrea, M.D., Bilir, T.E., Chatterjee, M., Ebi, K.L., Estrada, Y.O., Genova, R.C., et al., Eds.; Cambridge University Press: Cambridge, UK; New York, NY, USA, 2014; pp. 755-791.

10. Mach, K.J.; Kraan, C.M.; Adger, W.N.; Buhaug, H.; Burke, M.; Fearon, J.D.; von Uexkull, N. Climate as a risk factor for armed conflict. Nature 2019, 571, 193-197. [CrossRef] [PubMed]

11. Amusan, L.; Abegunde, O.; Akinyemi, T.E. Climate change, pastoral migration, resource governance and security: The Grazing Bill solution to farmer-herder conflict in Nigeria. Environ. Econ. 2017, 8, 35-45. [CrossRef]

12. Okoli, A.C.; Atelhe, G.A. Nomads against Natives: A Political Ecology of Herder/Farmer Conflicts in Nasarawa State, Nigeria, Okoli, Al Chukwuma and Atelhe George Atelhe. Am. Int. J. Contemp. Res. 2014, 4, 79.

13. Benjaminsen, T.A.; Alinon, K.; Buhaug, H.; Buseth, J.T. Does climate change drive land-use conflicts in the Sahel? J. Peace Res. 2012, 49, 97-111. [CrossRef]

14. Udeuhele, G.I. Urbanization and Insecurity in Nigeria: The Issues, Challenges and Prospect for National Development. MiddleEast J. Sci. Res. 2018, 26, 68-77. [CrossRef]

15. Odoh, S.I.; Chilaka, F.C. Climate change and conflict in Nigeria: A theoretical and empirical examination of the worsening incidence of conflict between Fulani herdsmen and farmers in Northern Nigeria. Arab. J. Bus. Manag. Rev. 2012, $34,1-15$. [CrossRef]

16. Amobi, D.; Onyishi, T. Governance and climate change in Nigeria: A public policy perspective. J. Policy Dev. Stud. 2015, 289, 1-12. [CrossRef]

17. Fasona, M.J.; Omojola, A.S. Climate change, human security and communal clashes in Nigeria. In Proceedings of the International Workshop on Human Security and Climate Change, Oslo, Norway, 21-23 June 2005; pp. 21-23, Organisers: Centre for the Study of Civil War, International Peace Research Institute, Oslo (PRIO) \& Centre for International Environmental and Climate Research at the University of Oslo (CICERO) for the Global Environmental Change and Human Security Program (GECHS).

18. Slettebak, R.T. Don't blame the weather! Climate-related natural disasters and civil conflict. J. Peace Res. 2012, 49, 163-176. [CrossRef]

19. Sayne, A. Climate Change Adaptation and Conflict in Nigeria. Available online: https://www.usip.org/sites/default/files/ Climate_Change_Nigeria.pdf (accessed on 18 December 2019).

20. Nossiter, A. Toll from Religious and Ethnic Violence in Nigeria Rises to 500. New York Times, 8 March 2010. Available online: https:/ / cfec.typepad.com/files/article---central-nigeria-violence---3-08-10---ny-times.pdf (accessed on 30 December 2019).

21. Bearak, M. Retrieved from The Washington Post. Available online: https://www.washingtonpost.com/news/world/wp/2018/1 2/10/feature/the-ordinary-people-keeping-the-peace-in-nigerias-deadly-land-feuds/ (accessed on 30 December 2019 ).

22. Conroy, S. Land conflicts and lethal violence in Nigeria: Patterns, mapping and evolution (2006-2014). IFRA-Niger. Work. Pap. Ser. 2014, 38, 1-38.

23. Kwaja, C.M.; Ademola-Adelehin, B.I. The Implications of the Open Grazing Prohibition and Ranches Establishment Law on Farmer-Herder Relations in the Middle Belt of Nigeria, 1st ed.; Search Common Ground: Washington, DC, USA, 2017; p. 8.

24. De Juan, A.; Hänze, N. Climate and cohesion: The effects of droughts on intra-ethnic and inter-ethnic trust. J. Peace Res. 2021, 58, 151-167. [CrossRef]

25. Taiye, F. Controlling the advancement of Savanna into southwestern Nigeria. Zonas Áridas 2007, 11, $251-259$.

26. Muhammed, I.; Ismaila, B.A.; Bibi, M.U. An assessment of farmer-pastoralist conflict in Nigeria using GIS. Int. J. Eng. Sci. Invent. 2015, 4, 23-33. 
27. Ibirogba, F. National Livestock Plan is Ruga in Disguise, Nigerians Warn. Available online: https://guardian.ng/features/agrocare/national-livestock-plan-is-ruga-in-disguise-nigerians-warn/ (accessed on 17 December 2019).

28. Soyinka, W. Ruga: Cattle Cannot Take Priority over Human Beings. Available online: https://www.channelstv.com/2019/07/02 / ruga-cattle-cannot-take-priority-over-human-beings-says-soyinka/ (accessed on 18 December 2019).

29. Channels Television. Federal Government Suspends Planned RUGA Programme. Available online: https: / / www.channelstv com/2019/07/03/breaking-news-federal-government-suspends-planned-ruga-programme/ (accessed on 18 December 2019).

30. Ogo-Oluwa, O. Anti-Grazing Policy and Conflict Resolution between Fulani Herdsmen and Farmers in Ekiti State. Asian Res. J. Arts Soc. Sci. 2017, 4, 1-13. [CrossRef]

31. Abuh, A. Miyetti-Allah Urges FG to Establish Livestock Ministry, Insists Open Anti-Grazing Law Unconstitutional Available online: https://guardian.ng/news/miyetti-allah-urges-fg-to-establish-livestock-ministry-insists-open-anti-grazinglaw-unconstitutional/ (accessed on 17 December 2019).

32. Ukoji, V.N.; Ayodokun, A.V.; Eze, V.C. Nigeria Watch: Eight Report on Violence in Nigeria. Ph.D. Thesis, IFRA-Nigeria, University of Ibadan, Ibadan, Nigeria, 2019.

33. Olagunju, T. Drought, desertification and the Nigerian environment: A review. J. Ecol. Nat. Environ. 2015, 7, 196-209. [CrossRef]

34. Wayumba, R. Developing Land Information Management Systems for County Governments in Kenya. IOSR J. Eng. 2017, 7, 42-49. [CrossRef]

35. Okeke, O.E. Conflicts between Fulani herders and farmers in central and southern Nigeria: Discourse on proposed establishment of grazing routes and reserves. AFRREV IJAH An. Int. J. Arts Humanit. 2014, 3, 66-84.

36. Maitima, J.M.; Mugatha, S.M.; Reid, R.S.; Gachimbi, L.N.; Majule, A.; Lyaruu, H.; Mugisha, S. The linkages between land use change, land degradation and biodiversity across East Africa. Afr. J. Environ. Sci. Technol. 2009, 3, 300-325.

37. Boles, O.J.C.; Shoemaker, A.; Courtney Mustaphi, C.J.; Petek, N.; Ekblom, A.; Lane, P.J. Historical ecologies of pastoralist overgrazing in Kenya: Long-term perspectives on cause and effect. Hum. Ecol. 2019, 47, 419-434. [CrossRef]

38. Ogunwale, A.O. Deforestation and Greening the Nigerian Environment. Available online: http:/ / eprints.covenantuniversity.edu. ng/5327/ (accessed on 13 May 2021).

39. Institute for Economics \& Peace. Global Terrorism Index 2019: Measuring the Impact of Terrorism, Sydney, November 2019. Available online: http:/ / visionofhumanity.org/reports (accessed on 3 January 2020).

40. Asaka, J.O. Climate Change-Terrorism Nexus? A Preliminary Review/Analysis of the Literature. Perspect. Terror. 2021, 15, 81-92.

41. Vivekananda, J.; Wall, M.; Sylvestre, F.; Nagarajan, C.; Brown, O. Shoring up Stability: Addressing Climate and Fragility Risks in the Lake Chad Region; Adelphi: Berlin, Germany, 2019.

42. Ifabiyi, I.P. Recharging the Lake Chad: The hydropolitics of national security and regional integration in Africa. Afr. Res. Rev. 2013, 7, 196-216. [CrossRef]

43. Usigbe, L. From Africa Renewal: December 2019-March 2020. Available online: https://www.un.org/africarenewal/magazine/ december-2019-march-2020/drying-lake-chad-basin-gives-rise-crisis (accessed on 8 April 2020).

44. Kabir, B.G.; Kagu, A.; Yerima, F.A. Agriculture, Cultural Interplay and Environmental Degradation on the Shores of the Lake Chad. In Issues in the Geography of Borno State; Adamu Joji Publishers: Kano City, Nigeria, 2009; pp. 43-49.

45. Genthon, P.; Hector, B.; Luxereau, A.; Descloitres, M.; Abdou, H.; Hinderer, J.; Bakalowicz, M. Groundwater recharge by Sahelian rivers-Consequences for agricultural development: Example from the lower Komadugu Yobe River (Eastern Niger, Lake Chad Basin). Environ. Earth Sci. 2015, 74, 1291-1302. [CrossRef]

46. Pearce, F. A Dam of Shame. Available online: http://www.waterafrica.co.za/index.php/contributors/67-fred-pearce/109-adam-shame (accessed on 11 April 2020).

47. Romero Hicks Murakami, L.F. Forced Migration, Conflict, and Climate Change in the Lake Chad Region: Perspectives on International Dynamics and the Anthropological Response to Enhancing Migrant Resilience and Community Cohesion. Master Thesis, Cornell University, Ithaca, NY, USA, 2020.

48. United Nations Office for the Coordination of Humanitarian Affairs (UNOCHA). Lake Chad Basin Crisis Overview. Available online: https:/ / reliefweb.int/report/nigeria/lake-chad-basin-crisis-overview-23-january-2019 (accessed on 12 April 2020).

49. Bleischwitz, R.; Johnson, C.M.; Dozler, M.G. Re-Assessing resource dependency and criticality. Linking future food and water stress with global resource supply vulnerabilities for foresight analysis. Eur. J. Futures Res. 2014, 2, 34. [CrossRef]

50. Caniglia, G.; Luederitz, C.; von Wirth, T.; Fazey, I.; Martin-López, B.; Hondrila, K.; Lang, D.J. A pluralistic and integrated approach to action-oriented knowledge for sustainability. Nat. Sustain. 2021, 4, 93-100. [CrossRef]

51. Okpara, U.; Stringer, L.; Dougill, A. Lake drying and livelihood dynamics in Lake Chad: Unravelling the mechanisms, contexts and responses. Ambio 2016, 45, 781-795. [CrossRef]

52. Hall, E.L. Conflict for resources: Water in the Lake Chad Basin. Army Command. Gen. Staff. Coll. Leavenworth Ks Sch. Adv. Mil. Stud. 2009, 15, 308-325.

53. Vichi, M. Transferring Water from the Congo to Lake Chad: The Transaqua project. Exec. Intell. Rev. 2011, 38, 31-36.

54. Sayan, R.C.; Nagabhatla, N.; Ekwuribe, M. Soft Power, Discourse Coalitions, and the Proposed Interbasin Water Transfer between Lake Chad and the Congo River. Water Altern. 2020, 13, 752-778.

55. Gil, J.; Siebold, M.; Berger, T. Adoption and Development of Integrated Crop-Livestock-Forestry Systems in Mato Grosso, Brazil. Agric. Ecosyst. Environ. 2015, 199, 395. [CrossRef] 
56. Moraine, M.; Duru, M.; Nicholas, P.; Leterme, P.; Therond, O. Farming System Design for Innovative Crop-livestock Integration in Europe. Animal 2014, 8, 1204-1217. [CrossRef] [PubMed]

57. Barron-Gafford, G.A.; Pavao-Zuckerman, M.A.; Minor, R.L.; Sutter, L.F.; Barnett-Moreno, I.; Blackett, D.T.; Macknick, J.E. Agrivoltaics provide mutual benefits across the food-energy-water nexus in drylands. Nat. Sustain. 2019, 2, 848-855. [CrossRef]

58. Cattivelli, V. Climate Adaptation Strategies and Associated Governance Structures in Mountain Areas. The Case of the Alpine Regions. Sustainability 2021, 13, 2810. [CrossRef]

59. Li, F.; Strachan, N. Take me to your leader: Using socio-technical energy transitions (STET) modelling to explore the role of actors in decarbonisation pathways. Energy Res. Soc. Sci. 2019, 51, 67-81. [CrossRef] 